\section{Influence of Egyptian Scorpion and Cobra Venoms on Mammalian Erythrocytes in vitro}

Kellaway and Williams' ${ }^{1}$ reported that Australian snake and Indian cobra venoms would cause hæmolysis of the red blood corpuscles of certain mammals, and that homologous serum mixed with the red blood corpuscles of these species inhibited hæmolysis. Using the red blood corpuscles of certain other species, the serum was found to activate hæmolysis. This led us to investigate the influence of the Egyptian scorpion and cobra venoms on mammalian erythrocytes in vitro.

The venoms were prepared from the Egyptian scorpion (Buthus quinquestriatus) and the Egyptian cobra (Naja tripudians) and were obtained in dry powdered form following the methods of Hassan, reported by me earlier ${ }^{2-4}$. Venom solutions were prepared by dissolving $10 \mathrm{mgm}$. of the powdered venom in $10 \mathrm{ml}$. of 0.85 per cent by volume sodium chloride solution. When not used, the solutions were stored at $-10^{\circ} \mathrm{C}$.

Human and rabbit's bloods were tested. Human blood was obtained by venipuncture. Rabbit's blood was withdrawn from the ear vein. In each case, $2 \mathrm{ml}$. of blood was placed in $50 \mathrm{ml}$. of 0.85 per cent salt solution and centrifuged. The supernatant plasma was thrown away. The red cells were washed six times in $50 \mathrm{ml}$. normal saline solution by the centrifuge method. $10 \mathrm{ml}$. of the blood was placed in a testtube and allowed to clot. The clotted blood was centrifuged and the supernatant serum withdrawn. The washed red cells and the serum of human and rabbit's blood were kept at $-10^{\circ} \mathrm{C}$.

The venoms were diluted before use 10, 20, 40 , $80,160,320,640,1,280,2,560,5,120$ times with normal saline solution. For every dilution of the venom, three small test-tubes were arranged to receive the following materials :

Tube i. $0.4 \mathrm{ml}$. venom, $0.1 \mathrm{ml}$. saline and $0.4 \mathrm{ml}$. washed red cells. Tube ii. $0.4 \mathrm{ml}$. venom, $0.1 \mathrm{ml}$. serum and $0.4 \mathrm{ml}$. washed red cells Tube iii. $0.4 \mathrm{ml}$. sallne, $0.1 \mathrm{ml}$. serum and $0.4 \mathrm{ml}$. washed red cells.

The tubes were kept at $37^{\circ} \mathrm{C}$. for $24 \mathrm{hr}$. The hæmolytic action was judged by the change of the opaque red mixture to translucent straw colour, and was confirmed by the disappearance of the red cells microscopically.

(A) Human blood. (1) Effect of scorpion venom on human red cells without and with serum:

$$
\text { DILUTIONS OF VENOM }
$$

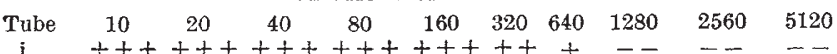

$$
\begin{aligned}
& \text { ii }++++++++++++++++++--1--1- \\
& \text { ii }+-\overline{\text { Complete hæmolysis. }++ \text { partial hæmolysis }}+-\overline{\text { homoly }} \\
& +++ \text {, Complete hæmolysis; }++ \text {, partial hæmolysis; }+, \text { hæmolysi }
\end{aligned}
$$

Conclusion. (1) Scorpion venom in concentration of $1 / 640$ or more hæmolyses human red cells; (2) human serum inhibits the hæmolytic effect of scorpion venom.

(2) Effect of cobra venom on human red cells without and with serum :

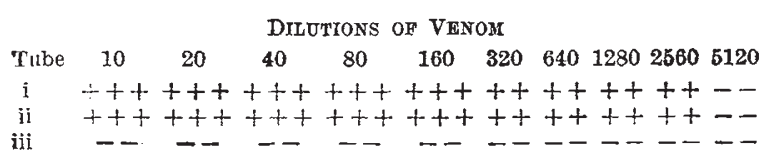

Conclusion. (1) Cobra venom in a concentration of $1 / 2,560$ or more hæmolyses human red cells; (2) human serum does not inhibit the hæmolytic effect of the cobra venom.

(B) Rabbit's blood. This experiment was performed to compare the effect of scorpion and cobra venoms on rabbit's red cells and rabbit's serum with the effect of the venoms on human red cells.

(1) Effect of scorpion venom on rabbit's red cells with and without rabbit's serum:

\section{DILUTIONS OF VenOM}

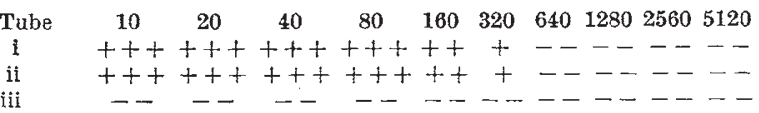

Conclusion. (1) Scorpion venom in a concentration of $1 / 320$ or more hæmolyses rabbit's red cells; (2) rabbit's serum does not inhibit the hæmolytic effect of scorpion venom.

(2) Effect of cobra venom on rabbit's red cells with and without rabbit's serum :

DILUTIONS OF VENOM

$\begin{array}{llllllllll}\text { Tube } \quad 10 & 20 & 40 & 80 & 160 & 320 & 640 & 1280 & 2560 & 5120\end{array}$

i $t+++t++t+++t+t+t++-----$ $+t+t+t+t+t+t+t++t+-----$

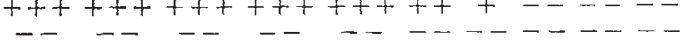

Conclusion. (1) Cobra venom in a concentration of $1 / 640$ or more hæmolyses the rabbit's red cells ; (2) rabbit's serum does not inhibit the hæmolytic effect of the cobra venom.

Kellaway and Williams ${ }^{1}$ reported that venoms must unite with lecithin before hæmolysis can occur. Red cells which have free lecithin in their stroma are capable of combining with the enzymes of the venom and can be hremolysed without an activator, which may be the plasma. Cells which do not have free lecithin in their stroma require an activator such as the serum or plasma. Kellaway ${ }^{5}$ suggested that the venom reacted with lecithin by splitting off one molecule of oleic acid. He said that lysolecithin is probably responsible for the prehæmolytic swelling of the red blood corpuscle and is inhibited by egg albumin. Feldberg et $a .^{6}{ }^{6}$ reported that lysolecithin, in addition to the hæmolytic action, also causes liberation of histamine from the perfused lungs. Zeller? claimed that the lecithinase of snake venom renders the capillaries more fragile by attacking the lipid layer of the endothelium and aids proteinase by producing internal hæmorrhages.

\section{A. H. Mohammed \\ H. ROHAYEM \\ O. ZAKY}

Department of Physiology, Abbassia.

Medical Faculty, University of Ibrahim, Cairo. Sept. 6.

${ }^{1}$ Kellaway, C. H., and Williams, F. E., Aust. J. Exp. Biol. and Med. Sci., 11, 75 .

2 Mohammed, A. H., Biochem. J., 38, 284 (1944).

${ }^{3}$ Mohammed, A. H., Lancet, i, 337 (1943).

"Mohammed, A. H., Lancet, ii, 716 (1949).

sellaway, C. H., "Ann. Rev. Biochem.", 8, 541 (1939).

' Feldberg, W., Holden, H. F., and Kellaway, C. H., J. Physiol., 94, 232 (1938).

"Zeller, E., “Advances in Enzymology”, 8, 487 (1048). 